\title{
TRANSIENT DIABETES IN INFANCY
}

\author{
BY \\ S. E. KEIDAN \\ From the Department of Child Health, University of Liverpool
}

(RECEIVED FOR PUBLICATION JANUARY 1, 1955)

Although diabetes mellitus is estimated to begin during the period of childhood in 5 to $8 \%$ of all cases (Nelson, 1954) it is quite rare in infancy. Recovery from diabetes at any age is even more rare and the few cases that have been reported have all been in infants. The case described here had a number of unusual features.

\section{Case Report}

Ann C. was admitted to hospital on June 26, 1953, at the age of 1 month. She was the third child of healthy parents and was born at full term following a normal delivery. No abnormality had been noted at birth and the birth weight was $6 \mathrm{lb}$. $2 \mathrm{oz}$. There was no family history of diabetes. She was breast fed for three weeks and then weaned on to feeds of full-cream National dried milk. For a week before admission she had seemed rather cross but she had taken her feeds well. There had been no vomiting, she had been passing formed yellow stools and there had been no polyuria. On the evening of admission her mother noticed that 'her head seemed to have sunk in at the top' and that her colour seemed poor.

On admission she weighed $6 \mathrm{lb} .2 \mathrm{oz}$. (expected weight $7 \mathrm{lb} .6 \mathrm{oz}$.). She was pale, wasted and grossly dehydrated, the most striking feature being the deep depression of the anterior fontanelle. A small boil was present on the left thigh but no other septic lesions were visible and no other abnormal physical signs were present on systemic examination. In view of the severe degree of dehydration intravenous fluid therapy was started immediately, beginning with half-strength plasma (diluted with Hartmann's solution) of which $300 \mathrm{ml}$. was given in the first eight hours. This was followed by N/5 saline with $5 \%$ glucose, $425 \mathrm{ml}$. being given over the next 15 hours. Thus the total parenteral fluid in 23 hours was $725 \mathrm{ml}$. based on a requirement of $100 \mathrm{ml}$. per pound of expected body weight, dehydration being assessed at more than $10 \%$. Towards the end of this period slight oedema of the eyelids and of the sacral region was noted and 19 hours after the start of the intravenous infusion she had a generalized convulsion lasting for a few minutes. Two further convulsions occurred an hour later while she was being examined. In each of these there was stiffening of the body, arching of the back and a brief period of apnoea. Apart from the slight oedema there were no abnormal findings. The anterior fontanelle was now of normal tension and there was no stiffness of the neck. Lumbar puncture was performed and bloodstained fluid under low pressure was obtained. She was sedated with chloral and, although there was no clear evidence of infection, it was considered that the initial dehydration and the subsequent convulsions were probably due to infection and treatment was started with penicillin (400,000 u. daily) and streptomycin (120 mg. daily). The baby's subsequent progress was uneventful. She fed well, gained weight steadily and convulsions did not recur. She was discharged from hospital after seven weeks, having gained over $3 \mathrm{lb}$. in weight (Fig. 1).

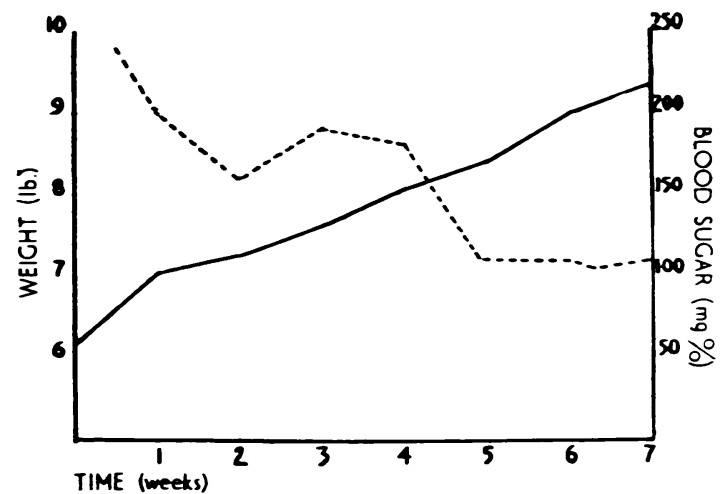

Fig. 1.

Investigations. The main interest in this patient lay in the laboratory findings rather than the clinical picture and so these are given in some detail.

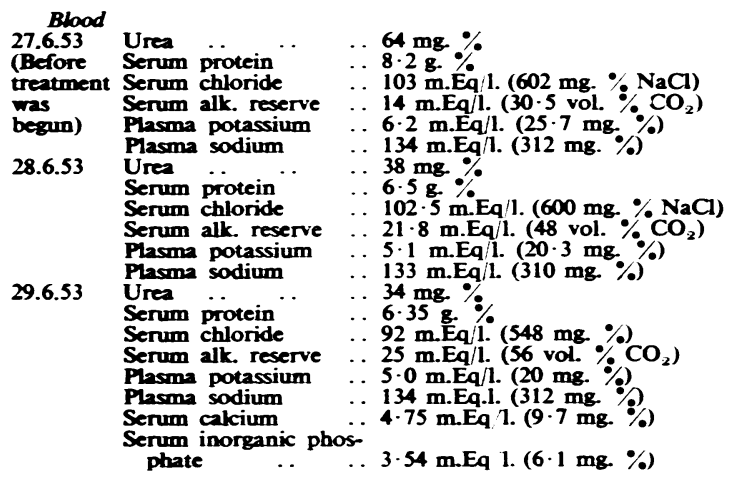


C.S.F. (xanthochromic bloodstained specimen)

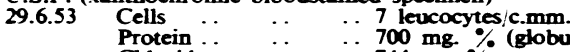
Chloride
Sugar
. $700 \mathrm{mg}$
$744 \mathrm{mg} . \%$
. No bacterial growth obtained

Because of the high level of the sugar a further specimen of cerebrospinal fluid was examined on June $\mathbf{3 0}$ and the result showed $170 \mathrm{mg}$. ${ }^{\circ}$ sugar. Paper chromatography confirmed that the sugar was glucose. A specimen of blood taken at the same time gave a value of $245 \mathrm{mg}$. \% of glucose and the urine was found to contain $0.2 \mathrm{~g} . \%$ of reducing substances. Unfortunately this first specimen was not tested for acetone.

Over the next three weeks, while the baby was taking normal feeds of National dried milk with added sugar, the blood sugar varied from 110 to $240 \mathrm{mg}$. \%. The estimations were usually done immediately before a feed, the feeding being on a four hourly schedule. Sugar continued to be present in the urine in amounts varying from 0.5 to $2.0 \mathrm{~g} . \%$, until July 17 when it became, and remained, sugar free. Acetone was only detected on one occasion at a time when the child was quite well and the fasting blood sugar level was $190 \mathrm{mg}$. \%. No sugar was found in the bulked urine for that day. The total volume of urine passed was measured on three separate days and varied from 154 to $344 \mathrm{ml}$. The lower figure may be incorrect as the difficulties of collecting total urine specimens from female babies are considerable. The upper figure is well within the normal range for a baby of 1 month.

A glucose tolerance test was performed on July 2 with the following result:
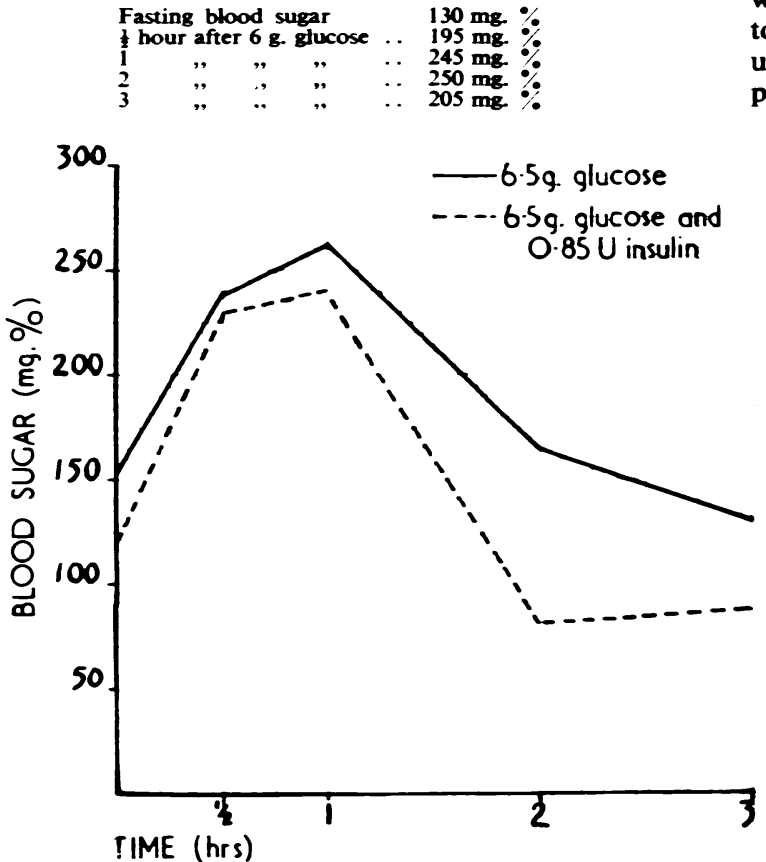

Fig. 2-Glucose tolerance test on July 15 .
This is a typical curve of moderately severe diabetes. In view of the child's satisfactory progress and the absence of any ketonuria, treatment did not seem indicated immediately. Dietary regulation is very difficult in an infant and it was by no means certain that the diabetic state would be sensitive to insulin. In order to investigate this a glucose/insulin tolerance test was performed. The glucose tolerance test was first repeated on July 15 with the following result (Fig. 2):

\begin{tabular}{|c|c|c|c|}
\hline \multirow{2}{*}{\multicolumn{3}{|c|}{$\begin{array}{l}\text { Fasting blood sugar } \\
1 \text { bour after } 6.5 \mathrm{~g} \text {. glucose }\end{array}$}} & \multirow{3}{*}{$\begin{array}{ll}152 & \mathrm{mg} . \\
240 & \mathrm{mg} . \\
263 & \mathrm{mg} \\
165 \mathrm{mg} .\end{array}$} \\
\hline & & & \\
\hline & & & \\
\hline
\end{tabular}

On the following day the glucose/insulin tolerance test showed:

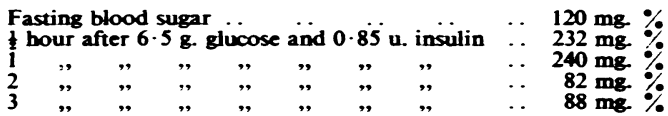

The tests were repeated one week later (July 21) with the following results (Fig. 3):

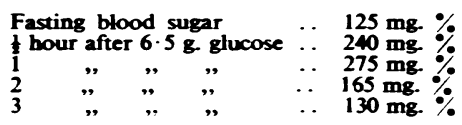

And on July 22:

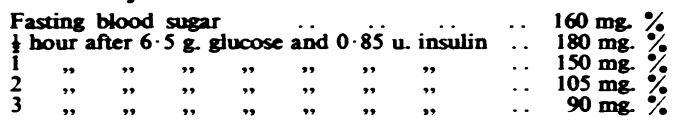

It seemed clear from this second test that the diabetes was now sensitive to insulin, but as the baby continued to thrive and neither sugar nor acetone was present in the urine, treatment was still withheld and the level of the pre-prandial blood sugar gradually fell to normal.

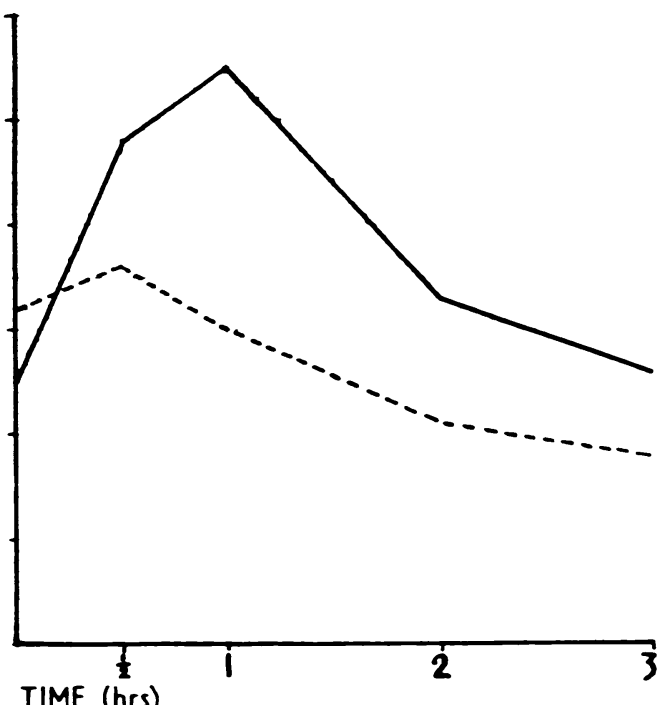

TIME (hrs)

FiG. 3.-Glucose tolerance test on July 21. 
Other investigations that were performed included lumbar puncture on June $\mathbf{3 0}$ when protein was $750 \mathrm{mg}$. ${ }^{\circ}$ and sugar $170 \mathrm{mg}$. ${ }^{\circ}$. On July 1 the cerebrospinal fluid was bloodstained and the supernatant slightly xanthochromic with 135 leucocytes per c.mm $\left(96^{\circ}\right.$ o mononuclears) and 16,000 R.B.C.s per c.mm. No bacterial growth was found on culture.

Lumbar puncture on July 8 gave a clear colourless fluid with 8 leucocytes per c.mm., protein, $60 \mathrm{mg} .{ }^{\circ}$; globulin, positive; chlorides, $708 \mathrm{mg} .{ }_{0}^{\circ}$ : and sugar, $144 \mathrm{mg}$. $\%$.

On July 28 protein was $70 \mathrm{mg} .{ }^{\circ}$; globulin, positive ; chloride, $712 \mathrm{mg} .{ }^{\circ}$; sugar, $100 \mathrm{mg}$. ${ }^{\circ}$.

On August 6 protein was $45 \mathrm{mg} .{ }^{\circ}$; globulin, negative; chloride, $708 \mathrm{mg}$. ${ }^{\circ}$ and sugar $100 \mathrm{mg}$. ${ }^{\circ}$ '.

Liver function tests on July 3 gave alkaline phosphatase, $14 \cdot 5$ units (King-Armstrong); thymol flocculation, negative; thymol turbidity, $1 \cdot 6$; zinc turbidity, $2 \cdot 4$; serum bilirubin, less than $0.5 \mathrm{mg}$. ${ }^{\circ}$.

Two-way chromatography of urine on July 3 showed glycine and alanine only. No fluid was obtained on subdural puncture at two sites on both sides of the head.

A Wassermann test was negative.

Radiography of the skull and spine showed no abnormality.

Following discharge from hospital the baby continued to thrive and at the age of 10 months weighed $21 \mathrm{lb} .4 \mathrm{oz}$. The blood sugar half an hour after a feed was $140 \mathrm{mg}$. \%. The mother was unwilling to allow the baby to be re-admitted to hospital for further studies and did not keep subsequent out-patient appointments. The family doctor reported that the child seemed perfectly well and normal in every way.

\section{Discussion}

In their critical review of the literature on diabetes in infancy, Lawrence and McCance (1931) accepted the diagnosis as proven in cases

(1) Where definite wasting, thirst, polyuria and preferably ketonuria were present, accompanied by a heavy glycosuria (over $2 \%$ ), whether the reducing substance was actually proved to be glucose or not, even if hyperglycaemia was not established: or (2) where, if symptoms and glycosuria were slight, definite and recurrent hyperglycaemia (over $0.2 \%$ ) was established.

On the other hand they rejected cases

(3) Which show only one or two symptoms suggestive of diabetes, in which glycosuria was only slight and might be due to lactosuria (not infrequent in infants) or to renal glycosuria. (4) Cases in Group 2 above in which hyperglycaemia is present but in which is never excessive (i.e. under $0.3 \%$ ) and which may be explained by a temporary infection or disease of the central nervous system such as trauma, tuberculous meningitis or hydrocephalus.'

These criteria would now have to be modified. Both galactosaemia and the de Toni-Fanconi syndrome may present with this vague clinical picture associated with mellituria. In order to substantiate the diagnosis of diabetes mellitus it should certainly be established that the reducing substance-whether in the blood, C.S.F. or urine-is glucose and that there is a persisting hyperglycaemia. The case described above would only have fitted into Group 1 on the day of admission, for the child's subsequent progress was quite normal even though definite and persistent hyperglycaemia was established. It was never excessive, however, and did not exceed $0.3 \%$ even after a dose of glucose. Moreover the changes in the cerebrospinal fluid, which are discussed below, might be interpreted as having been due to some intracranial disturbance which would bring the case into Group 4. A high prolonged curve in a glucose tolerance test can occur in a number of conditions (Behrendt, 1949). It is found in various liver diseases, with or without jaundice, such as glycogen storage disease and fatty infiltration of the liver. There was no clinical evidence of liver disease in this patient and the liver function tests were perfectly normal. Furthermore, the impaired glucose that occurs in severe liver disease is relatively insensitive to insulin (Himsworth, 1949). Severe infections may lead to glycosuria and hyperglycaemia (Himsworth, 1949; MacLean and Sullivan, 1929) indistinguishable from that in diabetes as long as the infection lasts. It is probable that persisting diabetes after such infection only occurs in an individual who is hereditarily or constitutionally predisposed. An acute infection could not be entirely excluded in this patient but there was little positive evidence. There was only slight fever and that was on the day of admission when she was severely dehydrated; there were no abnormal physical findings apart from one small boil, the leucocyte count was normal and a blood culture was sterile after eight days' culture.

Hyperglycaemia, usually brief, may occur as a rare complication of head injury. Although there was no history of post-natal injury in the present case injury sustained at birth cannot be entirely excluded. The baby was born at home following a labour lasting eight hours. She sucked well from the start and the neonatal progress was normal. Lumbar puncture was performed on the day after admission to hospital and the fluid, which was under low pressure, was slightly bloodstained; the supernatant fluid, after centrifuging, was xanthochromic and the protein content was high (700 mg. \%). A further lumbar puncture a few days later produced very little fluid, the protein content of which was between 700 and $1,000 \mathrm{mg} . \%$, and a third puncture on the following day produced no fluid at all. A cisternal puncture, however, 
produced a bloodstained fluid with a count of 16,000 red cells and 135 white cells (nearly all mononuclears) per c.mm. The supernatant fluid was also xanthochromic. A month later the cerebrospinal fluid flowed freely, was clear and the protein had fallen almost to normal limits. Although it was originally considered that there had been a traumatic tap at the first puncture, the subsequent changes in the cerebrospinal fluid made it more likely that there had been a subarachnoid haemorrhage which may have been present from birth. The precise relationship of this to the diabetic state remains obscure.

Diabetes resulting from a hypothalamic disturbance is usually insulin resistant but if the hyperglycaemia is persistent the islets may become exhausted and insulin-sensitive diabetes may supervene (Himsworth, 1949). The first glucose/insulin tolerance test, performed on July 16 , showed no fall in the blood sugar in the first hour whereas when the test was repeated one week later the blood sugar rose only by $20 \mathrm{mg}$. \% from the fasting state and at the end of the first hour it was below the fasting level. The dose of insulin used was based on the recommendation of Bridge and Mulholland (1948). They state that the normal response to a dose of 0.25 units of insulin per $\mathrm{kg}$. per body weight in the glucose-insulin test is a fall in the blood sugar of $30-35 \mathrm{mg} . \%$ at one hour as compared with the level at this time following a standard dose of glucose. A fall of less than $30 \mathrm{mg} . \%$ indicates insulin resistance. It is tempting to postulate that at the earlier stage the diabetes was caused by hypothalamic damage and that later on it became insulin-sensitive due to exhaustion of the islets. However, the hyperglycaemia was never marked and it is difficult to conceive that the function of islets would become deranged in so short a time. An alternative explanation for the differing results in the two glucose/insulin tests may lie in some difference in the rate of absorption of the insulin. In the first test the insulin was injected subcutaneously in the lateral side of the thigh and in the second test it was given into the deltoid area. Although, in the original test, there was no fall in the blood sugar level in the first hour, there was a sharp fall during the second hour and this may have been due to some delay in the absorption of insulin so that it did not begin to act for a longer time.

The literature on diabetes mellitus in infancy was fully reviewed by Lawrence and McCance in 1931 and again by Schwartzman, Crusius and Beirne in 1947. The latter authors discussed 57 cases which had been previously reported and they added a further one of their own. Since 1947, 22 further cases have been described (see Table 1) including the one reported in the present paper.

TABLE 1

REVIEW OF CASES OF INFANTILE DIABETES SINCE 1947

\begin{tabular}{|c|c|c|c|c|c|c|c|c|c|c|}
\hline \multicolumn{5}{|c|}{ Author } & \multirow{2}{*}{$\begin{array}{c}\text { Year } \\
1947\end{array}$} & \multirow{2}{*}{$\frac{\text { Sex }}{M}$} & \multirow{2}{*}{$\frac{\text { Age at Onset }}{10 \text { months }}$} & \multirow{2}{*}{$\begin{array}{c}\text { Family History } \\
\text { N.G. }\end{array}$} & \multirow{2}{*}{$\frac{\text { Ketonuria }}{\text { N.G. }}$} & \multirow{2}{*}{$\begin{array}{l}\text { Outcome } \\
\text { Died }\end{array}$} \\
\hline Whetter & et al. & $\cdots$ & . & . & & & & & & \\
\hline Guest & $\cdots$ & $\cdots$ & . & $\cdots$ & 1948 & $\begin{array}{ll}\text { 1. } & \mathbf{F} \\
\text { 2. } & \mathbf{M} \\
\text { 3. } & \mathbf{M}\end{array}$ & $\begin{array}{l}3 \text { months } \\
3 \text { months } \\
9 \text { days }\end{array}$ & 3 siblings & $\begin{array}{c}\text { N.G. } \\
- \\
-\end{array}$ & $\begin{array}{l}\text { Died } \\
\text { Lived, insulin } \\
\text { Lived, insulin }\end{array}$ \\
\hline Guest & . & $\cdots$ & . & . & 1949 & $\begin{array}{ll}\text { 1. } & \mathbf{M} \\
\text { 2. } & \mathbf{M} \\
\text { 3. } & \mathbf{M}\end{array}$ & $\begin{array}{l}7 \text { months } \\
10 \text { months } \\
11 \text { months }\end{array}$ & N.G. & $\begin{array}{l}\text { N.G. } \\
\text { N.G. } \\
\text { N.G. }\end{array}$ & $\begin{array}{l}\text { Lived, insulin } \\
\text { Lived, insulin } \\
\text { Lived, insulin }\end{array}$ \\
\hline Recalde & Cuesta & as et & & & 1950 & $\mathbf{M}$ & 5 months & - & - & Died \\
\hline Newcom & b et a & & $\cdots$ & $\ldots$ & 1951 & \begin{tabular}{l|l}
1. & \\
2. & \\
3. & N.G. \\
4. & N. \\
5. & \\
6. &
\end{tabular} & $\begin{array}{l}4 \frac{1}{2} \text { months } \\
7 \text { months } \\
10 \text { months } \\
10 \frac{1}{2} \text { months } \\
10 \frac{1}{2} \text { months } \\
12 \text { months }\end{array}$ & - in 2 cases & N.G. & $\begin{array}{ll}3 & \text { Died } \\
3 & \text { Lived }\end{array}$ \\
\hline Brodribt & et al & $\cdots$ & $\cdots$ & $\cdots$ & 1952 & $\begin{array}{l}\text { 1. } \mathrm{M} \\
\text { 2. } \mathrm{F}\end{array}$ & $\begin{array}{l}11 \text { months } \\
11 \text { months }\end{array}$ & - & - & $\begin{array}{l}\text { Lived, insulin } \\
\text { Lived, insulin }\end{array}$ \\
\hline Nawrock & ka-Kan & iska & $\cdots$ & $\cdots$ & 1952 & $\mathbf{M}$ & 12 days & - & - & Lived \\
\hline Wylie & $\cdots$ & $\cdots$ & . & $\cdots$ & 1953 & $\mathbf{F}$ & 17 days & - & - & Lived, insulin \\
\hline Arey & $\cdots$ & $\cdots$ & . & . & 1953 & $\mathbf{M}$ & 13 days & - & Trace & Lived \\
\hline Gans & $\cdots$ & $\cdots$ & $\cdots$ & $\cdots$ & 1954 & $\mathbf{M}$ & 39 days & - & - & Lived, insulin \\
\hline Hofman & -Bang. & E. & . & $\cdots$ & 1954 & $\mathbf{M}$ & 3 weeks & N.G. & - & Lived, insulin \\
\hline Present & case & $\ldots$ & . & $\ldots$ & 1954 & $\mathbf{F}$ & 27 days & - & Trace & Lived \\
\hline
\end{tabular}


Age Incideace. Both in Schwartzman's series and in the present series (Table 2) most cases occurred in the first and last quarters of the first year. Lawrence and McCance (1931) dispute the diagnosis in five of the cases in Schwartzman's series where the onset is said to have dated from birth. If these are eliminated the distribution would still be mainly at the beginning and the end of the first year.

TABLE 2

AGE AT ONSET OF DIABETES IN INFANCY

\begin{tabular}{|c|c|c|c|c|}
\hline & $\begin{array}{c}0-3 \\
\text { Months }\end{array}$ & $\begin{array}{c}3-6 \\
\text { Months }\end{array}$ & $\begin{array}{c}\text { 6-9 } \\
\text { Months }\end{array}$ & $\begin{array}{c}9-12 \\
\text { Months }\end{array}$ \\
\hline $\begin{array}{c}\text { Schwartzman et al. } \\
(1947) \ldots\end{array}$ & 18 & 10 & 8 & 14 \\
\hline Present series & 8 & 2 & 2 & 9 \\
\hline
\end{tabular}

Sex Incidence. In 45 cases reviewed by Schwartzman in which the sex is mentioned there are 27 males and 18 females. In the present series the sex was not mentioned in six cases and of the remainder there were 12 males and four females. Of all cases reported to date, therefore, the incidence in males is almost double that in females.

Mortality. Of the $\mathbf{5 0}$ cases discussed by Schwartzman in which the outcome was known, 35 died $(70 \%)$. Before the introduction of insulin in 1924 the outcome was almost uniformly fatal. Of 26 cases death occurred in 23. Lawrence and McCance did not accept that the diagnosis was established in two of the cases which recovered and the outcome in the third was not known. In the period from 1925 to 1946 the mortality rate fell to $50 \%$ for the whole of the first year but it remained high for the first three months of life, seven deaths occurring in 11 cases. In the present series there were six deaths out of 22 cases $(27 \cdot 2 \%)$. In the first three months only one death occurred in eight cases. Newcomb, Farrell and Hand (1951) reported six cases occurring between the ages of $4 \frac{1}{2}$ and 12 months, three of which died. The age at onset of the fatal cases is not given and so the mortality rate for the last three separate quarters cannot be calculated.

Family History. In Schwartzman's series there was a positive family history of diabetes in 12 cases out of 28 in which it was mentioned $(43 \%)$. In the present series there was a positive history in six cases out of 14 in which details are given $(43 \%)$. For diabetes of all ages a hereditary factor is only present in about $25 \%$ of cases (Lawrence, 1941).

Transient Diabetes. A transient diabetic state in infancy would seem to be a very rare occurrence.
Only five established cases have been published, brief details of which are given in Table 3. They have all occurred in very young infants, the oldest being 6 weeks. The onset was rapid in every case with severe dehydration. Vomiting only occurred in one case and in the others there was no excessive fluid loss from the bowel to account for the rapid dehydration. In only one case (Strandqvist, 1932) was there a definite associated infection. In the case recorded by Lawrence and McCance gangrene of the skin was present and the authors consider that this was secondary to the diabetic state. It is, however, quite possible that the gangrene was due to a severe necrotizing infection. In Ramsay's (1926) case the infant had a fever and 'an upper respiratory infection'. No details of this are given and an apparent respiratory infection is one of the diagnostic pitfalls in infantile diabetes (Newcomb et al., 1951). In Arey's (1953) case also a mild pharyngitis was said to have been present but is not likely to have been the cause of the profound disturbance. The cerebrospinal fluid was examined in only one other case besides the present one and the findings in both were very similar, the protein and sugar were raised and the fluid was xanthochromic. In NawrockaKanska's case (1952) vomiting was a marked feature but unfortunately the pressure of the cerebrospinal fluid was not recorded. In neither case in which the cerebrospinal fluid was abnormal was there a history of injury at birth and both infants progressed quite normally for the first two or three weeks. Nor was there a history of intracranial birth injury in the remaining four infants. Conversely, no record could be found of any infant with unequivocal evidence of intracranial injury at birth who developed hyperglycaemia. The significance of the cerebrospinal fluid changes, therefore, remains uncertain.

Despite the severity of the wasting and dehydration, marked ketonuria occurred in only one case. In two others traces of acetone were found but not until some days after the diabetic state had been recognized and when clinical improvement had occurred. The presence of acetone did not seem to be related to the height of the blood sugar level nor to the severity of the condition.

There was no family history of diabetes in any of the patients and it is not considered likely that they are 'potential diabetics' showing their trait in response to some form of stress. Ramsay's patient was reported to be in good health and fit for military service 25 years later (Arey, 1953).

Although insulin was used in the treatment of four patients the doses used were so small that it is doubtful if it was really necessary. Ramsay's patient had 0.5 units three times daily; Strandqvist gave 
TABLE 3

REVIEW OF CASES OF TRANSIENT DIABETES IN INFANCY

\begin{tabular}{|c|c|c|c|c|c|c|c|c|c|}
\hline \multicolumn{3}{|l|}{ Author } & \multirow{2}{*}{$\begin{array}{c}\text { Year } \\
1926\end{array}$} & \multirow{2}{*}{$\begin{array}{c}\text { Sex } \\
\mathbf{M}\end{array}$} & \multirow{2}{*}{$\begin{array}{c}\begin{array}{c}\text { Family } \\
\text { History }\end{array} \\
\text { Neg. }\end{array}$} & \multirow{2}{*}{$\begin{array}{c}\begin{array}{c}\text { Age at } \\
\text { Onset }\end{array} \\
3 \text { weeks }\end{array}$} & \multirow{2}{*}{$\frac{\begin{array}{c}\text { Highest } \\
\text { Recorded } \\
\text { Blood Sugar } \\
\text { (mg. \%) }\end{array}}{263}$} & \multirow{2}{*}{$\begin{array}{c}\text { Ketonuria } \\
\text { N.G. }\end{array}$} & \multirow[t]{2}{*}{ Clinical Features } \\
\hline Ramsay & $\cdots$ & 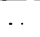 & & & & & & & \\
\hline Lawrence and $\mathrm{McC}$ & Cance & . & 1931 & $\mathbf{F}$ & Neg. & 15 days & 600 & - & $\begin{array}{l}\text { Gangrene of the skin, wasting and de- } \\
\text { hydration }\end{array}$ \\
\hline Strandqvist .. & . & . & 1932 & $\mathbf{M}$ & Neg. & 6 weeks & 420 & - & $\begin{array}{l}\text { Abscess of shoulder, wasting and de- } \\
\text { hydration }\end{array}$ \\
\hline Nawrocka-Kańska & . & $\ldots$ & 1952 & $\mathbf{M}$ & Neg. & 12 days & 268 & - & $\begin{array}{l}\text { Vomiting, dehydration, xanthochromic } \\
\text { C.S.F. }\end{array}$ \\
\hline Arey & . & . & 1953 & $\mathbf{M}$ & Neg. & 13 days & 555 & Trace & Rapid dehydration \\
\hline Present case & . & . & 1953 & $\mathbf{F}$ & Neg. & 4 weeks & 275 & Trace & Rapid dehydration, xanthochromic C.S.F. \\
\hline
\end{tabular}

1-2 units daily, Lawrence and McCance gave 1 unit four hourly and in Arey's patient the maximum dose on any day was $\mathbf{8}$ units. Although a definite clinical response was thought to occur after insulin had been given, the two babies who were not given insulin made similar, rapid recoveries. By contrast, a case of 'classical' diabetes mellitus in an infant of 39 days required $\mathbf{5 0}$ units of insulin hourly on the first day of treatment and was subsequently maintained on 26 units daily (Gans, 1954).

Direct studies of insulin sensitivity have not previously been reported but it is of interest that in Arey's case the blood sugar level remained high at least one week after insulin had been started and despite the marked improvement in the baby's general condition.

A review of these six cases offers little clue as to the aetiology of the condition. The evidence either for an infective basis or for a delayed result of intracranial birth injury is very slight and the very transience of the condition argues against any acute degenerative disorder. A 'toxic effect' on the carbohydrate-regulating mechanism of the brain (Strandqvist, 1932) or on the islet cells of an immature pancreas (Arey, 1953) has been postulated but begs the question as to the cause and mode of action of such a toxin. As all the known cases have recovered there has been no opportunity for morbid anatomical studies.

Although the condition is undoubtedly rare it is probable that more cases would come to light if the urine were routinely examined in every sick infant.

\section{Summary}

A further case of a transient diabetic state in a month-old baby is reported.

The literature on diabetes mellitus in infancy is reviewed.

I wish to thank Mr. J. T. Ireland for the many chemical investigations performed on this patient, and Professor N. B. Capon for his helpful criticism.

\section{References}

Arey, S. L. (1953). Pediatrics, 11, 140.

Behrendt, H. (1949). Diagnostic Tests for Infants and Children, p. 107. New York.

Bridge, E. M. and Mulholland, W. M. (1948). In Brennemann's Practice of Pediatrics, Vol. 3, Ch. 24. Hagerstown.

Brodribb, H. S., McMurray, J. and Scott, L. G. (1952). Brit. med. J. 1,1060 .

Gans, B. (1954). Proc. roy. Soc. Med., 47.132.

Guest, G. M. (1948). Amer. J. Dis. Child., 75, 461.

- (1949). Acta paediat., Uppsala, 38, 196.

Himsworth, H. P (1949). Lancet, 1, 465.

Hofman-Bang. E. (1954). Acta Paediat., Uppsala, 43, 393.

Acrece, R. A. (1931). Archives of Disease in Childhood, 6, 343.

Lawrence, R. D. (1941). The Diabetic Life, p. 10. Churchill. London.

Maclean, A. B. and Sullivan, R. C. (1929). Amer. J. Dis. Child., 37, 1146.

Nawrocka-Kanska, B. (1952). Pediat. pol., 27, 1067.

Nekon, W. E. (1954). In Textbook of Pediatrics, 6th ed., p. 1275. Philadelphia

Newcomb, A. L., Farrell. H. and Hand, A. (1951). Amer. J. Dis. Child., 81, 302.

Ramsay, W. R. (1926). Trans. Amer. pediat. Soc., 38, 100.

Recalde Cuestas, J. C., Staffieri, J. J. and Tommasino, P. S. (1950) Medicina, B. Aires, 10, 185.

Schwarteman, J. Crusius, M. E. and Beirne, D. P. (1947). Amer. J. Dis. Child. 74, 587.

Strandqvist, B. (1932). Acta paediat., Uppsala, 13, 421.

Whetter, R. W., Hodgson, M. R. and Janes, W. B. (1947). Manitoba

Wylie, M. E. S. (1953). Archives of Disease in Childhood, 28. 297. 